\title{
Nothofagus forest dynamics and palaeoenvironmental variations during the mid and late Holocene, in southwest Patagonia
}

\author{
Marcos E Echeverria, ${ }^{1,2}$ Gonzalo D Sottile, ${ }^{1,2}$ María V Mancini ${ }^{1}$ \\ and Sonia L Fontana ${ }^{3,4}$
}

\begin{abstract}
Southern Patagonia intersects the core of the Southern Westerlies, providing a unique opportunity for palaeo-reconstructions and the implication of past wind variations. There is a strong link between the strength of the westerlies and precipitation, which impacts vegetation communities. The palaeoenvironmental changes that occurred since the middle Holocene to present days are reconstructed from a peat record recovered in Peninsula Avellaneda $\left(50^{\circ} 15^{\prime} 57^{\prime \prime} \mathrm{S} ; 72^{\circ} 50^{\prime} 33^{\prime \prime} \mathrm{W}\right)$. Interpretations are based on pollen, charcoal and sediment analyses. Closed Nothofagus forest together with low fire activity characterized the region during the period c. 5500-3500 cal. yr BP, related to an increased in precipitation through an intensification of the westerlies. After 3500 cal. yr BP, shrub and grass communities became dominant at the expense of Nothofagus forest, suggesting a climatic shift to dry conditions, as a result of weaker westerlies. This patchy forest-steppe vegetation has favoured the occurrence of fire events. Subsequently, Nothofagus forest recovered for a short period between 2000 and 400 cal. yr BP. Then, major vegetation changes took place with the re-establishment of an open landscape. The calculated moisture balance index allowed us to hypothesize about the relationship between westerlies fluctuation and El Niño Southern Oscillation (ENSO) anomalies during the mid and late Holocene.
\end{abstract}

\section{Keywords}

fire regime, mid-late Holocene, Nothofagus, palaeoenvironmental reconstruction, pollen analysis, southwest Patagonia

Received 27 November 2013; revised manuscript accepted 9 April 2014

\section{Introduction}

The vast diversity of present vegetation and environments that occur throughout South America $\left(12^{\circ} \mathrm{N}\right.$ to $\left.56^{\circ} \mathrm{S}\right)$ is the result of diverse processes that have been operating and interacting at different spatial and temporal scales (Fontana et al., 2012). The west-east distribution of vegetation communities are related to the strong west-east precipitation gradient, nevertheless other environmental factors such as temperature, disturbances and the anthropogenic activities of the last century have triggered major vegetation changes (Fontana and Bennett, 2012; Jobbágy et al., 1996; Kitzberger, 2012).

Southern Patagonia (Figure 1a) is an important area to investigate the past variations of Southern Westerlies, because it is the only significant continental landmass that intersects the region of maximum zonal flow ( $49^{\circ}$ to $53^{\circ} \mathrm{S}$; Kilian and Lamy, 2012). There is a strong link between the strength of the westerlies and precipitation: enhanced atmospheric circulation promotes the growth of extratropical cyclones that are, in turn, steered by the $700 \mathrm{hPa}$ westerlies maximum and impinge on the South American continent (Garreaud and Aceituno, 2007). Years with higher precipitation correspond to periods of enhanced westerlies flow over the southern hemisphere (Moreno et al., 2009). Furthermore, the atmospheric circulation in the southern mid-latitudes is maintained by strong thermal gradients in the troposphere and seasurface temperatures over the Pacific Ocean (Moy et al., 2009).
Moreover, the Andean Cordillera is an important topographic barrier for the Pacific humid air masses; therefore, the mean annual precipitation decreases exponentially from west to east (Garreaud et al., 2009; Paruelo et al., 1998). A positive correlation exists between the precipitation and westerlies flow at $850 \mathrm{hPa}$, reaching highest correlations on the top of the mountain range, on the western side (Garreaud et al., 2013; Figure 5). The correlation becomes less significant on the leeward side of the Andes and turns negative towards the forest-steppe ecotone (Garreaud et al., 2009, 2013; Moreno et al., 2010; Moy et al., 2009). Several studies have indicated a positive correlation between precipitation and westerlies flow on the lee side of the Andes and their relationship with the distributions of the vegetation during the Holocene

\footnotetext{
'Universidad Nacional de Mar del Plata,Argentina ${ }^{2}$ CONICET, Argentina

3University of Göttingen, Germany

${ }^{4}$ Queen's University Belfast, UK
}

\section{Corresponding author:}

Marcos E Echeverria, Laboratorio de Paleoecología y Palinología, Departamento de Biología, IIMYC, CONICET, Universidad Nacional de Mar del Plata, Funes 3250, Mar del Plata 7600, Argentina.

Email: echeverriamarcos@hotmail.com 
a)

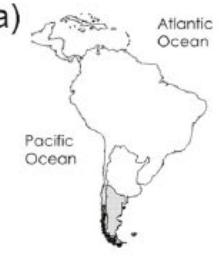

b)
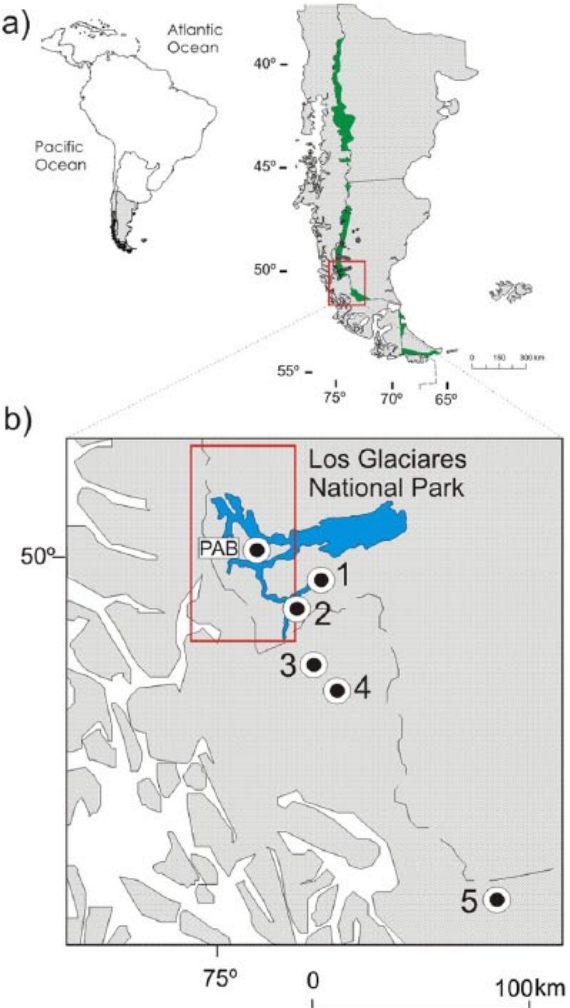

c)

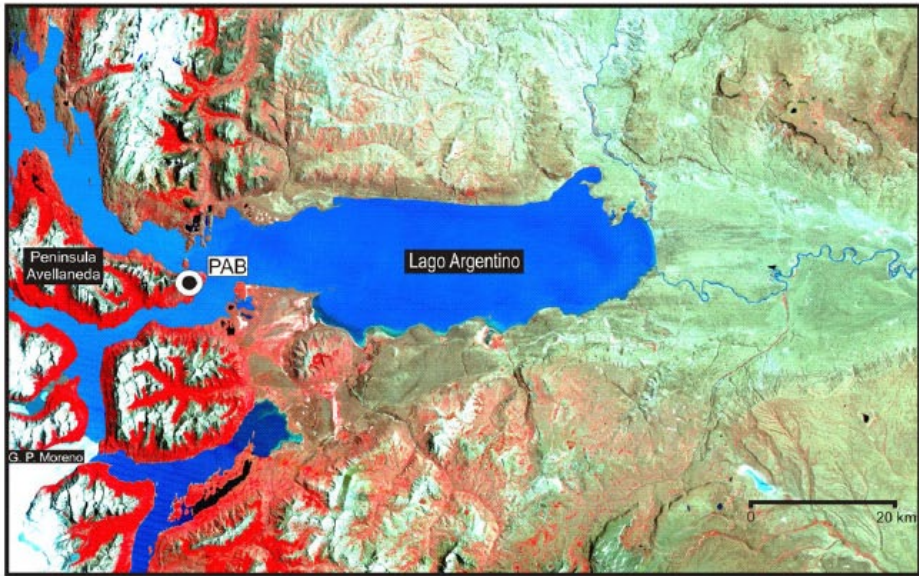

d)

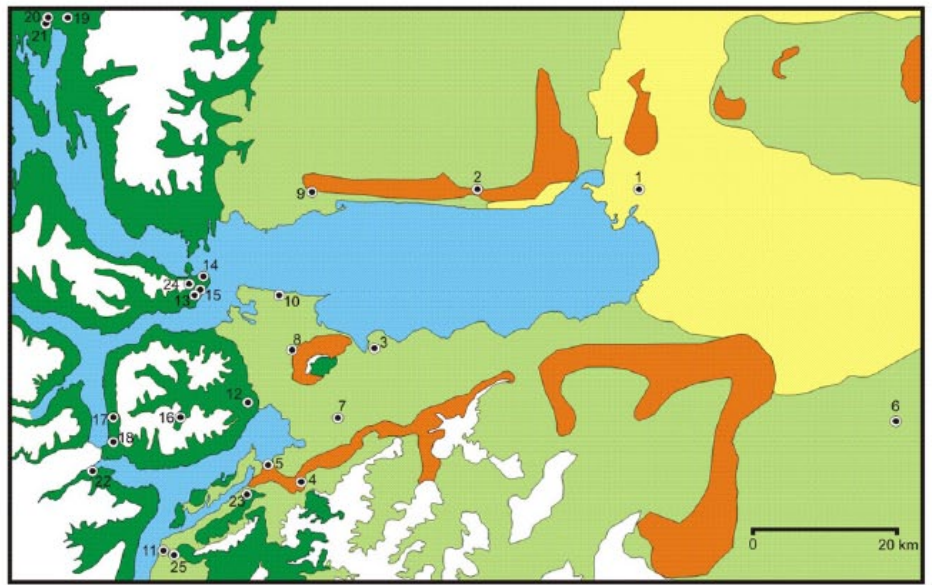

Figure I. Location of the study area and sampling sites: (a) Patagonia with the distribution area of Nothofagus (modified from Tonello et al., 2009). (b) Los Glaciares National Park and the sites mentioned in the text: (I) Cerro Frías (Mancini, 2009; Tonello et al., 2009); (2) Lago Argentino, Brazo Sur (Wille and Schäbitz, 2009); (3) Lago Guanaco (Moreno et al., 2009); (4) Vega Nandú (Villa-Martínez and Moreno, 2007) and (5) Rio Rubens (Huber and Markgraf, 2003). (c) False colour satellite image (Platform Landsat5, sensor TM) of Lago Argentino area, showing the location of Península Avellaneda Bajo peat record. (d) Lago Argentino vegetation units and surface samples (modified from Sottile et al., 2012).

(Bamonte and Mancini, 2011; de Porras et al., 2012; Mancini, 2009; Sottile et al., 2012; Tonello et al., 2009).

During the last decade, several studies analysed the behaviour of different proxies to the Holocene variability of the westerlies in southern Patagonia, interpreting the relationship between changes of the Intertropical Convergence Zone (ITCZ), El Niño Southern Oscillation (ENSO) and the westerlies (Bamonte and Mancini, 2011; Huber et al., 2004; Kilian and Lamy, 2012; Mancini, 2009; Masiokas et al., 2009; Schäbitz et al., 2013; Sottile et al., 2012; Tonello et al., 2009; Villa-Martínez and Moreno, 2007; Whitlock et al., 2007; Wille et al., 2007, among others). Garreaud et al. (2009) concluded that ENSO plays an important role in determining the interannual climate variability in South America. They indicate particularly the impact of ENSO on rainfalls regime in relationship with the fluctuations of the westerlies. However, there is no consensus about the mid and late Holocene palaeoenvironmental changes of southern Patagonia. Kilian and Lamy (2012) detected in their research several periods of regional climate change: the beginning of the 'Neoglacial' at $c$. $5500 \mathrm{cal}$. yr BP, the 3500-2500 cal. yr BP period, the 'Medieval Climate Anomaly' (MCA) and the 'Little Ice Age' (LIA). The MCA and the LIA ( $c$. $1450-450$ cal. yr BP and at c. 550-50 cal. yr BP respectively, sensu Bradley et al., 2003) are two periods of change not clearly recorded in southern Patagonia. However, Luckman and Villalba (2001) listed a series of glacial advances during this interval in southern Patagonia. Indeed, most glaciers of the Patagonian Ice Field are currently retreating from their historical maximum positions attained during the 'LIA' (Harrison and Winchester, 2000). Disentangling patterns and processes driving past biodiversity and dynamics changes are important to improve climate interpretations over southern hemisphere ecosystems.

Patagonia has been focus of several studies reaching global implications. However, palaeoecological reconstructions and palaeoclimatic interpretation from diverse latitudes and data sources are partly inconsistent and controversial (Kilian and Lamy, 2012). Examining vegetation changes jointly with fire history has proven to be a valuable approach to unravel past variations throughout Patagonia (Moreno et al., 2009). With the aim of improving our understanding about the vegetation dynamics of southwestern Patagonian and past variations in the westerlies, we studied a site in the east side of the Andes, within the Nothofagus forest, and faraway from human activities. We analysed the pollen and charcoal content of a peat core obtained in Península Avellaneda (Figure $1 \mathrm{~b}$ and $\mathrm{c}$ ). Supplementary information is provided by sedimentological analysis. In addition, surface samples from the different regional vegetation communities are analysed in order to assist the interpretation of the fossil record (Figure 1d). A correct understanding of the modern vegetation allows us to infer accurate changes in the past vegetation communities. The integration of these analyses provides palaeoenvironmental evidences that will help to understand the dynamics of the southwestern Patagonian forests, during the last 5500 years. To infer variations in the westerly winds based on changes in the vegetation, we assumed a significant positive correlation between the westerlies and the 
amount of local precipitation at the study site because of its close proximity to the mountain range.

\section{Vegetation communities of Península Avellaneda and surroundings}

Península Avellaneda is situated in the southwest of Santa Cruz province, in Argentina, within Los Glaciares National Park (Figure 1b). Present-day precipitation values in the peninsula ranges between 800 and $700 \mathrm{~mm} / \mathrm{yr}$. Average temperatures reach $14^{\circ} \mathrm{C}$ in summer and $3^{\circ} \mathrm{C}$ in the coldest months (meteorological data from 'Servicio Meteorológico Nacional, 2012'). Towards the east, precipitation decreases abruptly to $200 \mathrm{~mm}$ within $50 \mathrm{~km}$. Vegetation types mirror this pronounced precipitation gradient. The SubAntarctic forest occurs along the mountain range, where annual precipitation ranges between 800 and $400 \mathrm{~mm}$. Three Nothofagus species make up the forests of the region. Evergreen forests of Nothofagus betuloides are present in the southwestern sector of the National Park, where precipitation is higher $(850-600 \mathrm{~mm})$. Around the studied site, forests are dominated by the deciduous species Nothofagus pumilio and Nothofagus antarctica. N. pumilio is present at higher elevations on the mountain slopes. N. antarctica is a typical pioneer plant located near of the timberline in Patagonia and Tierra del Fuego but also tolerates wet conditions close to mires at any elevation. Under the Nothofagus canopy, subordinated trees such as Drimys winteri and Maytenus magellanica tolerate the shady environment, as well as Pteridophyta (e.g. Blechnum penna-marina) and rosettes herbs (e.g. Osmorhiza chilensis, Adenocaulon chilense, Viola magellanica; Pisano and Dimitri, 1973). The eastward limits of forest communities are mixed with steppe elements that colonized the burned forest patches and more arid environments. Embothrium coccineum and $N$. antarctica usually resprout after fire occurrence (Donoso et al., 2006), accompanied by heliophilous herbs and spiny shrubs (Vidal and Reif, 2011). In open forest (OF), shrubs and herbs as Berberis buxifolia, Mulinum spinosum, Empetrum rubrum, Escallonia rubra, Cerastium arvense, O. chilensis, Acaena pinnatifida, Lathyrus magellanicus, Poa and Festuca species are present. The grass steppe (GS) occurs towards the east, between 500 and 300 $\mathrm{mm}$ of mean annual precipitation and above the timberline, where climatic conditions are cold and wet. The shrub steppe (SS) is characterized by a dense cover of shrubs growing between 400 and $200 \mathrm{~mm}$ (Bamonte and Mancini, 2011).

Peat lands of diverse types occur throughout the region. They are frequently found in valley bottoms and low gradient slopes and have developed mostly over lacustrine sediment, after glacial retreat (Strelin and Malagnino, 2000). These postglacial peat formations contain sufficiently well-preserved micro- and macrofossils, representing valuable archives of environmental change during Holocene.

\section{Site description}

The studied site, called Península Avellaneda Bajo (PAB), is a peat bog dominated by Cyperaceae and Sphagnum species and surrounded by a mixed deciduous forest of $N$. pumilio and N. antarctica. Large cushions of $M$. spinosum and grasses are also common. The peat bog is located in the eastern slope of Península Avellaneda at $50^{\circ} 15^{\prime} 57^{\prime \prime} \mathrm{S} ; 72^{\circ} 50^{\prime} 33^{\prime \prime} \mathrm{W}, 215 \mathrm{~m}$ a.s.l. (Figure 1c). The peat bog is situated on a depression modelled by PleistoceneHolocene glacial advances (Glasser et al., 2004; Strelin et al., 2011). During the mid and late Holocene are postulated a series of glacial advances. A glacier advance is recorded between $c$. 5400 and 4900 cal. yr BP, as well as at several sites in the southern Andes (Aniya, 1995; Glasser et al., 2004). A subsequent minor advance occurred at c. 3800 cal. yr BP (Aniya, 1995; Kilian and Lamy, 2012; Luckman and Villalba, 2001; Moreno et al., 2009).
Another event is situated at $c .2000 \mathrm{cal}$. yr BP, and a subsequent expansion younger than c. 1300 cal. yr BP (Aniya, 1995; Glasser et al., 2004; Luckman and Villalba, 2001; Masiokas et al., 2009). Glaciers advances during the LIA period ranged between 600 and 50 cal. yr BP. During this period, many glaciers reached their maximum extension at $c .550 \mathrm{cal}$. yr BP, following a successive retreat until the last century (Kilian and Lamy, 2012; Masiokas et al., 2009).

Historical accounts tell that the arrival of the first explorers to the area of Lago Argentino was in 1873, lead by Lieutenant Valentine Feinberg (Polletti Formosa, 1979). In the 1920s, a family of Croats arrived at Lago Argentino and occupied the Península Avellaneda. In 1956, the peninsula was abandoned and became part of the Los Glaciares National Park (Perincioli, 2009). These activities have influenced local vegetation distribution and physiognomy.

\section{Methods}

\section{Sampling design and pollen analysis}

In order to study modern pollen-vegetation representation, we analysed the pollen content of 30 surface sediment samples that were collected from the surface to a depth of 1-2 cm following the multiple sampling method (Adam and Mehringer, 1975), between $49^{\circ} \mathrm{S}-51^{\circ} \mathrm{S}$ and $71^{\circ} \mathrm{W}-73^{\circ} 30^{\prime} \mathrm{W}$, representing the different vegetation types of the region: SS, GS, OF and closed forest (CF; Figure 1c). These samples are part of the pollen database of Santa Cruz province, held at the Palaeoecology and Palynology Laboratory, Mar del Plata University.

A 197-cm-long peat sequence was recovered using a Livingstone corer in 2010. The lowest part of the record consisted mostly of inorganic material; therefore, the $103 \mathrm{~cm}$ topmost section is considered in this study. Sub-sampling of the core was performed at 4-cm intervals, and every $2 \mathrm{~cm}$ in sections where a better resolution was required for pollen-charcoal comparison.

Pollen samples were processed in the laboratory of Palaeoecology and Palynology (Mar del Plata University) following standard methods. A known weight of sample was analysed after drying in an oven at $60^{\circ} \mathrm{C}$ during $6 \mathrm{~h}$. Sample weight ranged between $\leq 1$ and 8 g. Lycopodium clavatum was added to each sample prior to chemical treatment to estimate the pollen concentration and pollen accumulation rate. Modern and fossil samples were sieved through 120 and $70 \mu \mathrm{m}$ meshes, respectively, and treated with $\mathrm{KOH}, \mathrm{HCl}, \mathrm{ZnCl}_{2}, \mathrm{HF}$ and acetolysis (Faegri and Iversen, 1989). In addition, the short centrifuging technique (Brown, 1960) was applied to the fossil samples to remove the remaining fine organic matter.

The main pollen sum of terrestrial vascular plants ranged between 250 and 750 grains. Pteridophyta and Cyperaceae were not included in the sum because they represent local vegetation. Also, Asteraceae subf. Cichorioideae and Rumex (Polygonaceae) were excluded because they represent mostly exotic taxa by anthropic impact, and Podocarpus was excluded by representing extra-regional vegetation. Pollen diagrams were performed with the program Tilia and TiliaGraph (TGView 2.0.2; Grimm, 2004) and presented in relative diagrams (percentage) of pollen grains and spores. Additionally, pollen concentration data were carried out for throughout the sequence (grains/g of sediment) to calculate pollen accumulation rate. The groups of modern samples and zonation of the fossil sequence were performed using the grouping technique cluster analysis with a Euclidean distance (TGView 2.0.2; Grimm, 2004).

The arboreal/non-arboreal pollen ratio (AP/nAP) was calculated to illustrate changes in relative dominance of forest/steppe vegetation and as an indicator for changes in the moisture balance. The AP/nAP ratio was standardized by subtracting the mean and dividing by the standard deviation. In order to highlight the 
general trend, a three-term moving average was applied. The resulting moisture balance index indicates positive anomalies for forest dominance and positive moisture balance and vice versa. Also, this index was compared with the ENSO reconstruction proposed by Rein et al. (2005) from a sediment core of the Peruvian coast.

\section{Chronology and sediment analysis}

The chronology of the sediment sequence $\mathrm{PAB}$ is based on four accelerator mass spectrometry (AMS) ${ }^{14} \mathrm{C}$ dates from different levels of peat (Table 1). CALIB 5.0.1 software (Stuiver et al., 2005) was used to calibrate the ${ }^{14} \mathrm{C}$ ages as years calibrated before present (cal. yr BP). Dates were calibrated with the Southern Hemisphere (SHCal04) calibration curve (McCormac et al., 2004). The age-depth model was obtained by MCAge software using a cubic smoothing spline and a bootstrap approach (Monte Carlo sampling; Higuera et al., 2009). The confidence intervals for the age-depth models, reflecting the combined uncertainty of all age estimates, were derived from 1000 bootstrapped chronologies. For each bootstrapped chronology, each age used to develop the chronology was selected randomly based on the probable distribution of calibrated ${ }^{14} \mathrm{C}$ dates. The final chronology represents the median age at each depth from all the runs. The decompression factor produced after the core extraction was included in the construction of the age-depth model. Furthermore, the sediment accumulation rate was calculated jointly with the age-depth model using this software.

The technique of loss on ignition (LOI) was applied to estimate the content of organic matter throughout the sequence. The analysis was carried out in successive 1-cm intervals. The samples were dried overnight at $105^{\circ} \mathrm{C}$ and followed by combustion at $550^{\circ} \mathrm{C}$ during $4 \mathrm{~h}$ in a muffle oven (Bengtsson and Enell, 1986; Heiri et al., 2001). In addition, the dry bulk density $\left(\mathrm{g} / \mathrm{cm}^{3}\right)$ was estimated on the same levels of pollen samples. Samples of known volume $\left(1 \mathrm{~cm}^{3}\right)$ were dried at $90^{\circ} \mathrm{C}$ for $12 \mathrm{~h}$.

\section{Charcoal records}

Macroscopic charcoal analysis was undertaken to reconstruct local fire history following Whitlock and Larsen (2001) methods. Sediment samples of $1 \mathrm{~cm}^{3}$ were taken at contiguous $1-\mathrm{cm}$ intervals and soaked in $\mathrm{KOH}$, and then in bleach for $24 \mathrm{~h}$. They were washed through 250 - and $125-\mu \mathrm{m}$ mesh screens, and residues were counted under a stereomicroscope. Charcoal particles were classified in grass and wood particles. In order to infer the severity of fire events, a fire severity index was calculated as grass/total charcoal ratio (Sottile et al., 2012). Charcoal particles $>250 \mu \mathrm{m}$ and between 250 and $125 \mu \mathrm{m}$ were summed together as they show the same patterns. Charcoal concentrations (number of particles/ $\mathrm{cm}^{3}$ ) were multiplied by sedimentation rate $(\mathrm{cm} / \mathrm{yr})$ to obtain the charcoal accumulation rate (CHAR; particles/ $\mathrm{cm}^{2} / \mathrm{yr}$ ) of each sample. Charcoal data were interpolated to constant 17 years, corresponding approximately to the median temporal resolution of the record.

Low-frequency variations in a charcoal record, $\mathrm{C}_{\text {background }}$, represent changes in charcoal production, sedimentation, mixing and sampling and were subtracted to obtain a residual series, $\mathrm{C}_{\text {peak }}$. A Gaussian mixture model was used for each sample to identify the $\mathrm{C}_{\text {noise }}$ distribution. According to Tolonen (1983), fire history from peat is generally less powerful than from those of lake sediments. Only local fires ( $<500 \mathrm{~m}$ distance from the bog) may leave detectable carbon horizons especially at small basins (Conedera et al., 2009; Higuera et al., 2007). Thus, calibration of charcoal deposition on peat sequences with known historic fire episodes is crucial to interpret past local fire records and $\mathrm{C}_{\text {noise }}$ distribution. The 85 th, 90th and 95th percentiles of the $\mathrm{C}_{\text {noise }}$ distribution were considered
Table I. Radiocarbon dates from Pensinsula Avellaneda Bajo (PAB). Material analyzed bulk organic matter.

\begin{tabular}{lrcl}
\hline Sample depth $(\mathrm{cm})$ & Age ${ }^{14}$ C yr BP & Age cal.yr BP & Lab code \\
\hline $25-26$ & $9 \pm 38$ & -2 & AA99349 \\
$53-54$ & $365 \pm 34$ & 393 & AA93729 \\
$77-78$ & $1550 \pm 20$ & 1374 & UGAMS\#10587 \\
$99-100$ & $4555 \pm 55$ & 5151 & AA8935 I \\
\hline
\end{tabular}

as possible thresholds separating samples into 'fire' and 'non-fire' events, but the 85 th percentile was chosen for peak plotting and peak analysis. This percentile was the accurate threshold that allowed us to detect statistically the most recent fire episode ( $\sim 1000$ ha burned) that took place in the surrounded forest areas of the peat bog registered by the botanist Pérez Moreau (1959) $c$. AD $1930 / 1950$ probably associated to anthropic activities on the eastern side of the Península Avellaneda. $\mathrm{C}_{\text {background }}$ was estimated with a locally weighted regression using a 500-year window in order to maximize the signal-to-noise index and the goodness-of-fit between the empirical and the modelled $\mathrm{C}_{\text {noise }}$ distributions (Higuera et al., 2009). All statistical treatments were done using the program CharAnalysis (Higuera et al., 2009; http://CharAnalysis.googlepages.com).

Past fire regime characteristics were inferred based on the magnitude and temporal pattern of identified charcoal peaks. Peak magnitude, the number of charcoal pieces from all samples defining a given peak, is a measure of total charcoal deposition per fire event (Whitlock et al., 2006). Changes in peak magnitude at millennial scales were used as a qualitative proxy for average fuel consumption per fire. The temporal characterization of fire regime was inferred by the fire frequency pattern (peaks/kyr) with a 700-year window and compared with pollen zones (Higuera et al., 2009).

\section{Statistical analysis}

Rarefaction analysis has frequently been used in palaeoecology to estimate palynological richness, which has been interpreted to represent changes in landscape diversity (Birks and Line, 1992). Therefore, palynological richness was applied to explore past trends connected to the forest-steppe dynamics. This analysis was carried out using Psimpoll 4.27 (Bennett, 2003). It estimates the number of pollen types based on a common pollen sum (the lowest sum of the group of samples being compared; Birks and Line, 1992).

A cross-correlation analysis was performed to evaluate the synchrony between the moisture balance index and CHAR influx. We selected two time periods that included the highest CHAR values of the sequence: $0-1000 \mathrm{cal}$. yr BP and 500-5500 cal. yr BP. The trend of the moisture balance index before and after the peak on CHAR influx was analysed in each period independently. Diagrams of cross-correlation were plotted for each time period. The cross-correlation analyses were performed using the freely available software R (R Development Core Team 2011) using the library stats that is part of the software R available online (Wessa, 2013; http://www.wessa.net/).

Principal Component Analysis (PCA) was applied to display the relationships between the samples, with the direction of variation of different significant taxa. Detrended Correspondence Analysis (DCA) performed a priori indicates a gradient length of 2.175 standard deviations for the first axis, suggesting that underlying responses are linear (Legendre and Birks, 2012). The PCA analysis was carried out on the cross-products matrix of variance/ covariance (centred), and variables scores were calculated by weighted averaging. Both analyses were carried out on taxa exceeding $5 \%$ of the total terrestrial pollen sum in more than one 
sample. In addition, a correlation analysis was performed to evaluate the relationship between the first two PCA axes and the main pollen taxa.

Ecological regime shifts can be defined as abrupt changes on several trophic levels (Lees et al., 2006), leading to rapid ecosystem reconfiguration between alternative states. These shifts are generally thought to be driven by external perturbations (e.g. climatic fluctuations, invasive species, etc.), but the exact mechanism is often unclear (Andersen et al., 2008). Abrupt ecosystem changes often result from nonlinear dynamics, although this need not always be the case, as such changes can also result from linear state changes in response to abrupt changes in abiotic conditions (Andersen et al., 2008). Ecological regime shifts are identified by PCA of the fossil pollen data, showing the temporal shift patterns on the first PCA axis. This regime shift analysis could be interpreted as a gradual or abrupt vegetation change.

\section{Result}

\section{Chronology and sediment description}

The age-depth model (Figure 2) provides a time control for the studied sequence spanning the last $5500 \mathrm{cal}$. yr BP. Changes in sediment composition are displayed in Figure 2 and described in Table 2. Two distinct sand layers are recognized at $c .102 \mathrm{~cm}, c$. 5500 cal. yr BP and at $c .75 \mathrm{~cm}, c .1500$ cal. yr BP, coinciding with low values of organic matter. The development of neighbouring gullies by running water may have increased the input of inorganic material into the basin during these periods. A thin light-grey tephra layer is present at $c .5500 \mathrm{cal}$. yr BP probably produced by the eruption of Aguilera volcano. This tephra layer is also present in other sequences of the area (Mancini, 2009; Stern, 2008; Tonello et al., 2009; Villa-Martínez and Moreno, 2007).

\section{Modern pollen data}

The cluster analysis defines different units of vegetation representing the typical communities: SS, GS, open and closed Nothofagus forest (Figure 3). The SS is represented by Asteraceae subf. Asteroideae or Mulinum (40\%), and secondarily by Poaceae (20\%); the GS is dominated by Poaceae (60-70\%), while Asteraceae subf. Asteroideae is present with values of $10 \%$; Nothofagus characterized forest communities: the OF shows lower values of Nothofagus (40-60\%), presenting other important taxa, such as Poaceae, Acaena, Mulinum, E. rubrum and Asteraceae subf. Asteroideae, and in CF, Nothofagus is present with $75-90 \%$ of abundance, together with Misodendrum (5\%).

\section{Fossil pollen and charcoal data}

The pollen sequence was divided into four assemblage zones obtained by cluster analysis. The pollen assemblages (Figure 4) together with the charcoal data (Figure 5) can be described as follows:

Zone 1 (103-92 cm depth, 5500-3600 cal. yr BP). Nothofagus presents its highest values in the sequence, $80-90 \%$. Additionally, Drimys is registered only in this zone, with low values $(\leq 5 \%)$. Asteraceae subf. Asteroideae increases its values to the top (35\%), and Pteridophyta occurs with $40 \%$ of abundance at the beginning of the zone. The palynological richness is low. CHAR values are low $\left(0-0.054\right.$ pieces $/ \mathrm{cm}^{2} / \mathrm{yr}$; Figure $\left.5 \mathrm{a}\right)$. Fire regime is characterized by low fire frequency $(0.7-2$ fires per 700 years) and low peak magnitude ( $<1.6$ pieces $/ \mathrm{cm}^{2} /$ peak $)$, reaching the lowest values at c. $4600 \mathrm{cal}$. yr BP (Figure 5a). Zone 2 (92-81 cm depth, 3600-2000 cal. yr BP). This zone is characterized by Asteraceae subf. Asteroideae (40-55\%) together with other shrubs and herbs such as E. rubrum,
Ericaceae, Berberis, Caryophyllaceae, Acaena and Fabaceae (all with values lower than $10 \%$ ). Poaceae occurs with values between $10 \%$ and $20 \%$, and Nothofagus presents $40 \%$ at the beginning of the zone, decreasing towards the top. The palynological richness is higher than in Zone 1 . CHAR values ranges between 0 and 0.48 pieces $/ \mathrm{cm}^{2} / \mathrm{yr}$. Fire frequency increases towards c. $2600 \mathrm{cal}$. yr BP (4 fires per 700 years). Peak magnitude values are similar to Zone 1 . The highest peak magnitude recorded for this zone at c. 2300 cal. yr BP coincides with high CHAR values and fire frequency (Figure 5a). There is a decreasing trend in fire frequency towards $c$. 2000 cal. yr BP.

Zone 3 (81-54 cm depth, 2000-400 cal. yr BP). Nothofagus dominates this zone, and its values increase up to $60 \%$ towards the top of the zone. Misodendrum exhibits values of up to $20 \%$. Understory vegetation is characterized by Poaceae $(15 \%)$ and Caryophyllaceae $(\leq 20 \%)$. Asteraceae subf. Asteroideae decreases its values to about $20 \%$. Pteridophyta values are nearly the same as in the beginning of Zone 1 and the end of Zone 2 (50\%). In this zone, the palynological richness decreases. CHAR values range between 0 and 0.23 pieces $/ \mathrm{cm}^{2} /$ yr. Fire frequency peaks around c. $1000 \mathrm{cal}$. yr BP (3.5 fires per 700 years), decreasing toward c. $400 \mathrm{cal}$. yr BP. Peak magnitude values remain low $\left(<3.12 \mathrm{pieces} / \mathrm{cm}^{2} /\right.$ peak $)$.

Zone 4 (54-0 cm depth, 400 cal. yr BP to present). Nothofagus curve decreases abruptly from $60 \%$ to $20 \%$, however, increasing again towards the present to about $40 \%$, similarly to Pteridophyta. Misodendrum is low $(\leq 5 \%)$. Poaceae dominates the zone with $60 \%$ of abundance. Caryophyllaceae values reach $20 \%$. Other herbs such as Brassicaceae, Acaena, Chenopodiaceae and Fabaceae occur with low values $(\leq 10 \%)$. Mulinum presents the highest values in this zone $(20 \%)$. Other shrubs registered are Asteraceae subf. Asteroideae, E. rubrum, Ericaceae and Berberis (all of them with $\leq 10 \%$ ). The curve of Cyperaceae increases notably, showing values near to $65 \%$. Asteraceae subf. Cichorioideae (25\%) and Rumex $(\leq 5 \%)$ are also present in this zone. Palynological richness is low at the beginning of the zone, increasing to the top. Char values are the highest of the record (1.3436.23 pieces $/ \mathrm{cm}^{2} / \mathrm{yr}$ ). Fire frequency remains stable ( 2 fires per 700 years). The highest peak magnitude of the record reaches 1500 pieces $/ \mathrm{cm}^{2} /$ peak at c. 350 cal. yr BP. A second highest peak magnitude is detected around c. 25 cal. yr BP (210 pieces $/ \mathrm{cm}^{2} /$ peak).

The severity index shows medium to high values throughout the last c. 600 cal. yr BP (Figure 5a). The global signal-to-noise index is 3.07. The SNI is $>3$ over Zone 4 and Zone 3, indicating a fire signal consistently separated from $C_{\text {noise }}$ (Kelly et al., 2011). The SNI fluctuates around 1-2.8 in Zone 1 and partially in Zone 3. Therefore, higher SNI coincide with OFs inferred by pollen assemblages. On the contrary, $\mathrm{CF}$ environments coincide with the lowest SNI, possibly related to the extremely low biomass burning probability (Kitzberger et al., 2012).

\section{PCA}

The results of PCA separate the samples into clusters that correspond well with the zonation of the fossil pollen data and with modern pollen-vegetation data. The first axis (PC1), explaining $62.11 \%$ of the variance, splits the samples according to their proportion of Poaceae (eigenvector $=0.53$ ) versus Nothofagus (eigenvector $=-0.82$ ). The second axis (PC2), which explained $17.99 \%$ of variance, separated the samples according to their proportion of Poaceae (eigenvector $=0.61$ ) versus Asteraceae subf. Asteroideae (eigenvector $=-0.70$ ). This is supported by the correlation among the variables with their axis. Poaceae presents a 


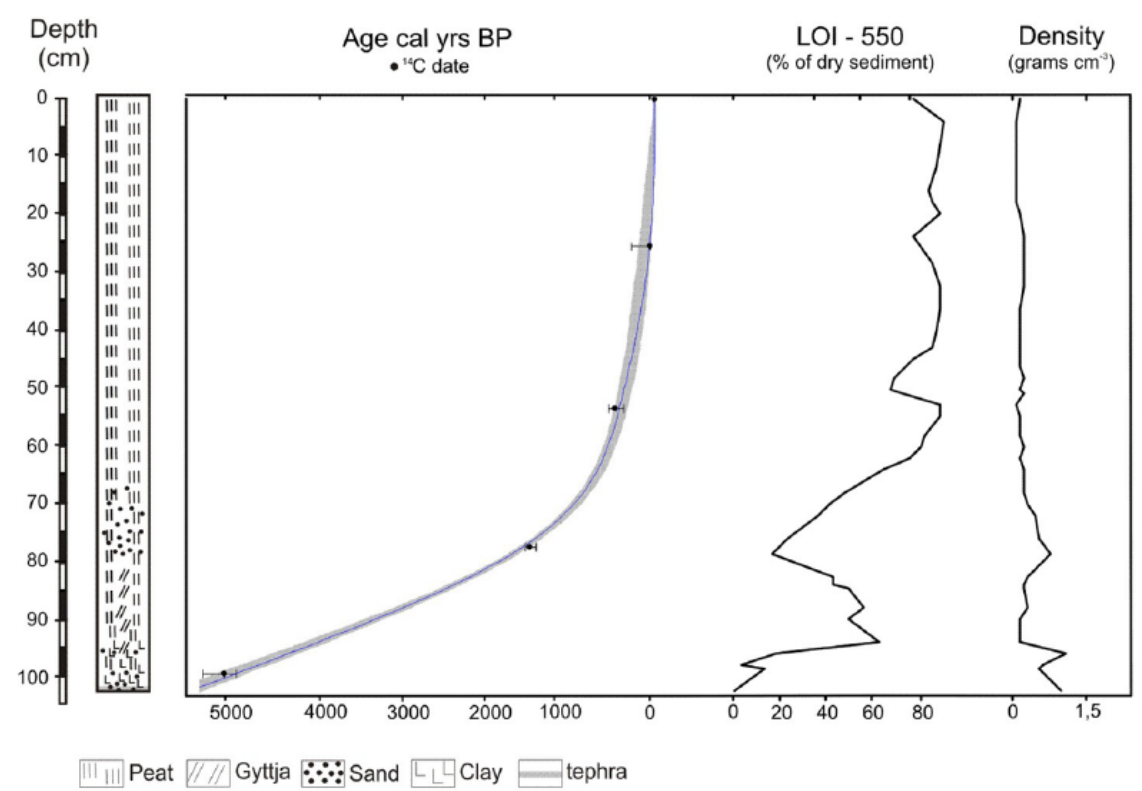

Figure 2. Sediment description, age-depth curve, loss on ignition and density from Peninsula Avellaneda Bajo.

Table 2. Sediment description.

\begin{tabular}{lll}
\hline Depth $(\mathrm{cm})$ & Age cal.yr BP & Sediment characteristic \\
\hline $0-68$ & $\begin{array}{l}\text { Present-800 } \\
800-1500\end{array}$ & $\begin{array}{l}\text { Peat sediment with high concentration of plant fibres; organic matter between } 80 \% \text { and } 60 \% \text { and low density. } \\
\text { Peat sediment with presence of sand; organic matter drops to } 40-20 \% ; \text { peak of density towards the underly- } \\
\text { ing layer. }\end{array}$ \\
$\begin{array}{l}\text { Peat sediment with low concentration of plant fibres and dark gyttja; organic matter increases to } 60 \% \text { and } \\
\text { density drops to } 0.3 \mathrm{~g} / \mathrm{cm}^{3} .\end{array}$ \\
$\begin{array}{l}\text { Th-94 } \\
\text { Th-99 sediment is primarily composed by peat associated to high presence of clay, and less of sand and gyttja; } \\
\text { organic matter falls from } 20 \% \text { to } 5 \% \text {; peak of density to } 1.8 \mathrm{~g} / \mathrm{cm}^{3} \text { at } 96 \mathrm{~cm} . \\
\text { Sandy clay sediment with a tephra layer at } 102 \mathrm{~cm} \text {; low organic matter }(<5 \%) ; \text { density increases towards to } \\
\text { the bottom. }\end{array}$ \\
\hline
\end{tabular}

positive correlation with both axis, higher with PC1 $(r=0.831)$ than PC2 $(r=0.514)$; Nothofagus shows a high negative correlation with PC1 $(r=-0.971)$, and Asteraceae subf. Asteroideae with PC2 $(r=-0.872)$.

Figure 6 shows the ordination of the samples into five groups. Group 1 is characterized by the presence of modern pollen samples of the cluster CF and the samples of Zone 1 (fossil pollen data), and this area is mainly dominated by high proportion of Nothofagus. The second group met most of the samples of the cluster OF and samples of Zone 3, which show lower proportion of Nothofagus than the previous area. Group 3 is in the positive extreme of the axis 1 and is mainly characterized by high proportion of Poaceae. This area is composed by most samples of Zone 4 and modern samples of unit grass steppe. The modern unit shrubs steppe is grouped in an area characterized by the proportion of Poaceae, Asteraceae subf. Asteroideae, Mulinum and Fabaceae (Group 4). The last set (Group 5) comprises the samples of Zone 2, and its location is explained, principally, by the high proportion of Asteraceae subf. Asteroideae, indicating that Zone 2 assemblages have no modern equivalent.

\section{Discussion}

\section{Vegetation and fire history of Península Avellaneda}

The modern pollen samples, following the west-east rainfall gradient of southern Patagonia, are used to identify the different physiognomic types of vegetation and their relationship with climate at a spatial scale. The comparison of fossil with modern data allows us to make inferences about the variations of the vegetation at different periods during the past.

Between 5500 and 3600 cal. yr BP, the dominant vegetation in the area of Península Avellaneda was a closed forest, inferred by high Nothofagus values (between $60 \%$ and $90 \%$ ) and the presence of $D$. winteri, which is able to tolerate high levels of shade under the canopy of Nothofagus. Closed mature Nothofagus forests are substantially less flammable than open canopy patches (Kitzberger et al., 2012). This closed canopy community displays strong self-thinning processes that results, in the long term, in a physical separation of the main canopy and the understory layer, often composed of shade-tolerant species. Closed forest presents high resilience to be affected by fire (Willis and Bhagwat, 2010), which in our data is indicated by the low fire frequency and low palynological richness. A shade carpet, consisting of Pteridophyta (e.g. B. penna-marina), characterized this kind of understory. Modern analogues of this type of Nothofagus forest occur at locations receiving $700-800 \mathrm{~mm}$ precipitation annually, and these values may have been characteristic for this period.

A major physiognomic change occurred after 3600 cal. yr BP. Shrubs, mainly Asteraceae subf. Asteroideae, became dominant for about 1400 years at the expense of Nothofagus, suggesting climatic shifts from wet to dry conditions. This is accompanied by an increase in palynological richness, associated to the opening of the canopy, which facilitates the input of sunlight, available space and in consequence the development of herbs and shrubs, resulting in an overall more open landscape. The climatic conditions and low resilience of the community allowed an ecological shift, 


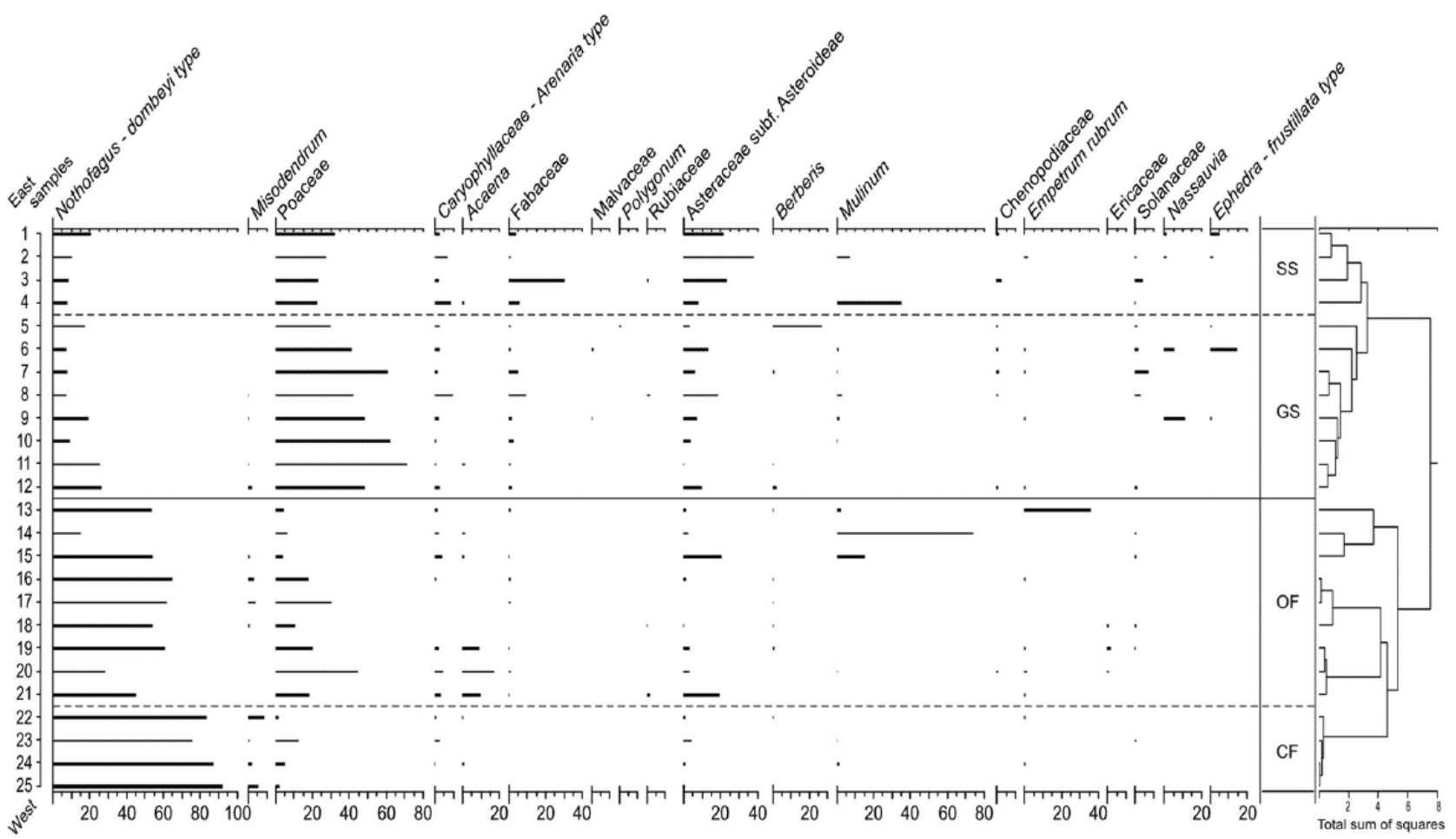

Figure 3. Pollen percentage values from surface samples. Samples are plotted by vegetation type, following an east-west precipitation gradient. SS: shrub steppe; GS: grass steppe; OF: open forest; CF: closed forest.

a peak of fire events at c. 2300 cal. yr BP. Figure $5 \mathrm{~b}$ shows a negative correlation between the time series of CHAR influx and the moisture balance index for these fires events, suggesting that the development of non-arboreal species (Asteraceae subf. Asteroideae) facilitated the occurrence of the event. Open canopy forests as well as patchy vegetation of steppe-forest communities are highly flammable because of heliophilous shrubs and herbs, which accumulate high volumes of flammable dead stems. Additionally, the presence of tall shrubs and young mature trees performs suitable vertical fuel continuity (Kitzberger et al., 2012). After that, the fire frequency decreased toward c. 2000 cal. yr BP.

From 2000 to $400 \mathrm{cal}$. yr BP, the fossil data indicate the recovery of the Nothofagus forest, suggesting wetter conditions than in the previous zone. In addition, the values of Poaceae, Caryophyllaceae and Asteraceae subf. Asteroideae and the decrease in palynological richness support the interpretation of an open forest. By analogy with modern conditions, we can infer rainfall values of $c$. $500-700 \mathrm{~mm} / \mathrm{yr}$ for this period. The preceding pattern of palaeovegetation and wetter climatic conditions probably decreased community's flammability.

The major physiognomic change took place after $400 \mathrm{cal}$. yr $\mathrm{BP}$, with prevalence of a grass steppe and reduction of the forest. The re-establishment of an open landscape suggests a decrease in the precipitation values compared with the previous period. This change in vegetation physiognomy favoured the occurrence of fires at c. $300 \mathrm{cal}$. yr BP. The cross-correlation analysis (Figure $5 c)$ shows a negative correlation, suggesting the presence of nonarboreal taxa (Poaceae) at the moment of high values of charcoal influx. Grass abundance favours horizontal fuel continuity, allowing surface fires to take place on these environments. Thus, the presence of shrubs and tree patches renewal performs vertical fuel continuity favouring crown fires (Kitzberger, 2003). These events are associated with an increasing trend in palynological richness of herbs and shrubs. Mulinum is perhaps the most outstanding species whose emergence and subsequent development occurs simultaneously with the disturbance. Acaena, Chenopodiaceae, Fabaceae, Brassicaceae and Berberis are some of the taxa that are accentuated or appear after the peak of charcoal. The wide availability of open sites allowed the establishment of low dispersion pollen type as Orchidaceae.

Since c. 70 cal. yr BP to present, natural disturbances have produced community heterogeneity and patch effect, generating open spaces depending on the state of the community before the disturbance (White and Pickett, 1985). As a result, a mosaic landscape with patches of Nothofagus and steppe communities of grasses and shrubs have characterized the region for the last 130 years. The most recent fire event is detected in the fossil record at c. 25 cal. yr BP (AD 1925), coinciding with the arrival of the first farmer to Península Avellaneda. The fire events are associated with a fluctuation in palynological richness and anthropic taxa, such as Asteraceae subf. Cichorioideae and Rumex, at the top of the sequence. Cyperaceae reaches maximum values in recent years, dominating the peat bog. Pollen accumulation rate is low throughout most of the sequence, except for the last 500 cal. yr BP when it increases remarkably (Figure 4). The higher pollen deposition during the last centuries could be related to an enhance catchment area.

\section{Palaeoclimatic reconstruction}

Beginning of the 'Neoglacial' at c. 5500-3500 cal. yr BP. Palaeoecological data of Península Avellaneda Bajo show presence of closed forest in this area and a positive trend in the moisture balance index (Figure 7a), probably related to an increase in precipitation through an intensification of the westerlies, until $c$. 4000 cal. yr BP. Also, high precipitation had restricted fire activity. Other pollen sequences such as Vega Nandú (Villa-Martínez and Moreno, 2007), Lago Guanaco (Moreno et al., 2009), Cerro Frías (Mancini, 2009) and Lago Argentino, Brazo Sur (Wille and Schäbitz, 2009; Figure 1b) indicate the prevalence of Nothofagus forest under wet conditions at a regional scale. Moreno et al. (2009) applied a Nothofagus/Poaceae (N/P) ratio to illustrate the degree of forest/steppe dominance, concluding that Nothofagus dominated woodlands in discrete pulses, one at c. $4400 \mathrm{cal}$. 


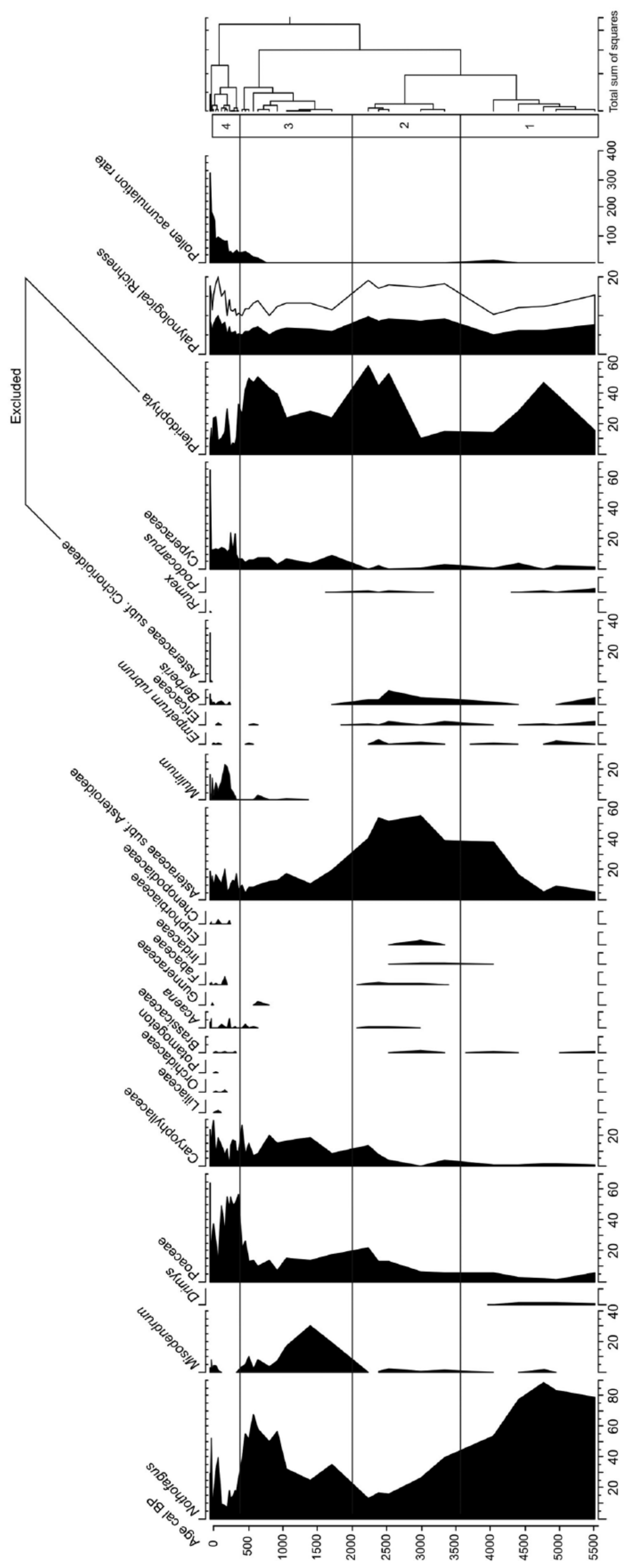

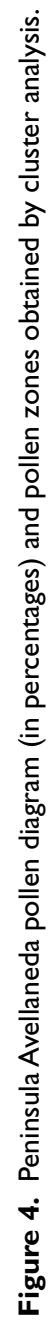




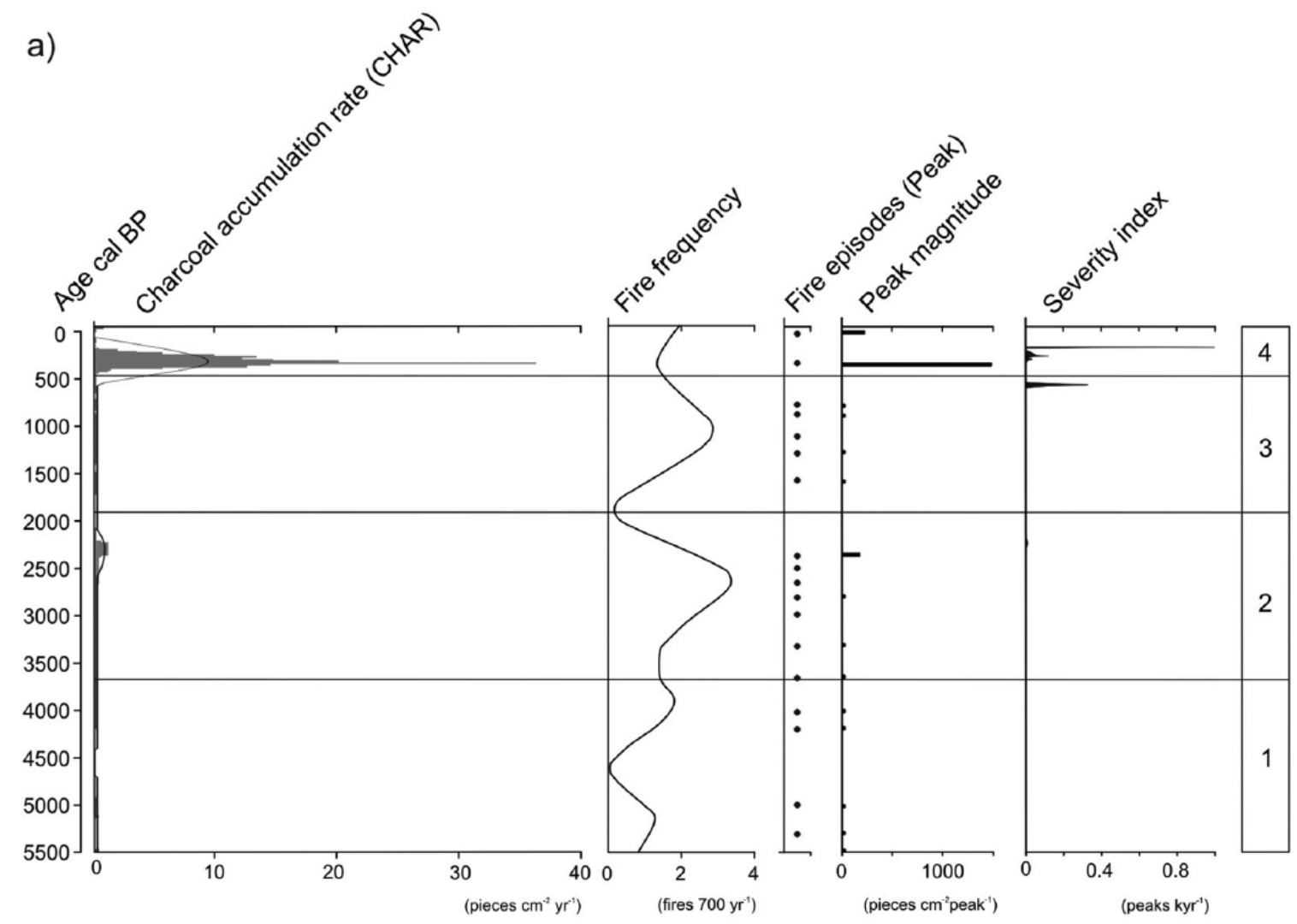

b)

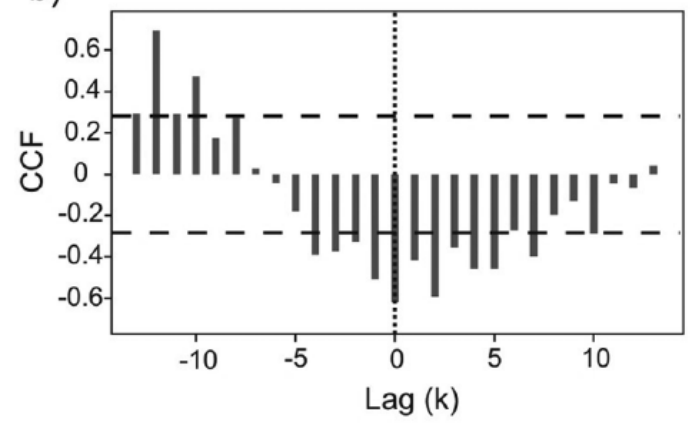

c)

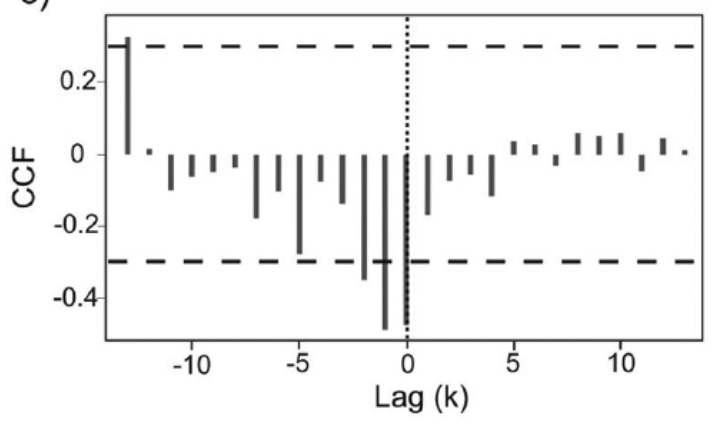

Figure 5. (a) Charcoal accumulation rates (CHARs), fire frequency, fire episodes, peak magnitude, severity index and pollen zones from PAB. (b and c) Cross-correlation analysis between water balance index of PAB and CHAR influx, 0-1000 cal. yr BP period and 500-5500 cal. yr BP period, respectively.

yr BP. In addition, Mancini (2009) inferred for this period Nothofagus forests similar to modern dense forests, which currently grow in high moisture conditions. Tonello et al. (2009) proposed a successive increase of precipitation at Cerro Frías during this period, with a Holocene maximum of $450-500 \mathrm{~mm} / \mathrm{yr}$ at c. 3500 cal. yr BP. These records indicate wet conditions by strengthening of the westerlies towards $c .4000 \mathrm{cal}$. yr BP. The regime shift analysis shows several changes (Figure 7b); the first shift at $c$. 4000 cal. yr BP is associated with a gradual change in the vegetation. After that, the forest dominance declines, possibly related to a Neoglacial advance at c. 4300-3800 cal. yr BP (Aniya, 1995; Kilian and Lamy, 2012; Luckman and Villalba, 2001; Moreno et al., 2009); the low temperatures could have restricted water availability.

Late Holocene (between c. 3500 and 2500 cal. yr BP). During this period, the moisture balance index for the PAB record shows a negative trend (Figure 7a). Nothofagus values drop, suggesting dry condition and weakening of the westerlies. Consequently, open vegetation communities dominated by grass and shrub species developed, resulting in increased fires. Weakening of the westerlies in southern Patagonia has been inferred by other authors through changes in vegetation communities. For example, at Cerro Frías, Nothofagus decreased after c. 3200 cal. yr BP, suggesting open forests and shrub expansion (Asteraceae subf. Asteroideae, Mulinum, Empetrum and Berberis; Mancini, 2009). According to the quantitative reconstruction by Tonello et al. (2009), the precipitation declined between c. 3000 and 2000 cal. yr BP. Wille and Schäbitz (2009) showed two reductions in Nothofagus values, the former at the beginning of this period and the second at c. $2600 \mathrm{cal}$. yr BP, enabling the increase of grasses and herbs. Moreno et al. (2009) interpreted a peak on Pediastrum values at 3200-2900 cal. yr BP as an evidence for warm conditions, suggesting the occurrence of the driest interval during the last 5000 years. In addition, the N/P ratio shows negative anomalies during this period (Moreno et al., 2009), indicating the predominance of Poaceae. The regime shift analysis shows a change at $c$. $2000 \mathrm{cal}$. yr BP (Figure 7b), associated with a gradual change in the vegetation. After that, the tendency in the moisture balance and forest dominance starts to increase (Figure 7a). 


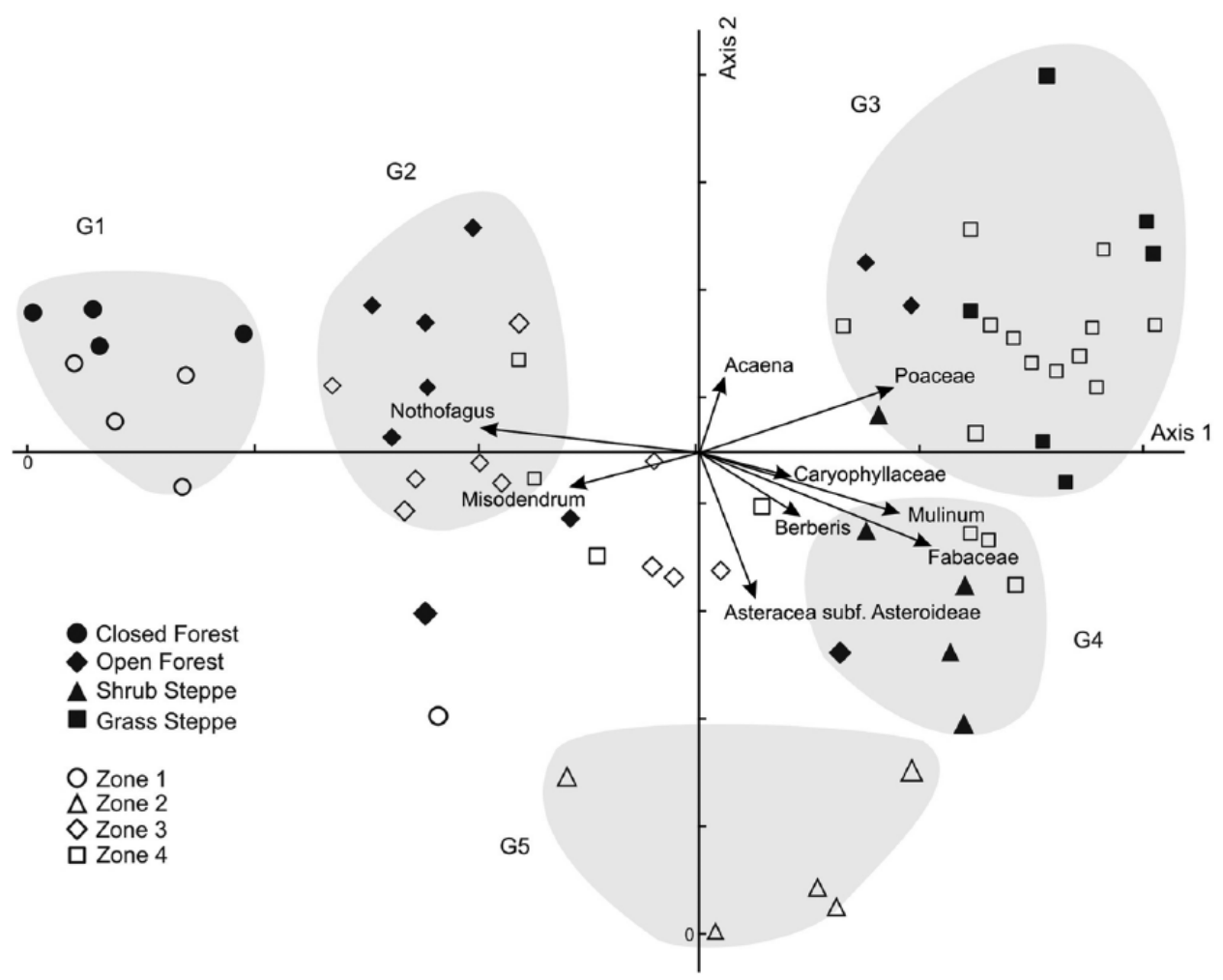

Figure 6. Principal Component Analysis from PAB sediment sequence and surface samples. GI-G5 represent the five groups obtained by the ordination.

PAB: Península Avellaneda Bajo.

MCA between c. 1450 and 450 cal.yr BP. Nothofagus record from Península Avellaneda provides evidence to the hypothesis of an open forest, with a trend from wet to dry conditions towards the end of this period. Other southern Patagonian sequences show similar signals for this period. Huber and Markgraf (2003) and Villa-Martínez and Moreno (2007) suggest that Nothofagus forest dominated modern ecotone areas. In Lago Guanaco, Moreno et al. (2009) identified a relative opening of woodlands, or mosaics with woodland and grass environments, occurring between $c$. 1400 and 570 cal. yr BP. In addition, Mancini (2009) found high values of Nothofagus at the beginning of this period, followed by a marked decrease at $c .800 \mathrm{cal}$. yr BP, suggesting a grass steppe expansion. Tonello et al. (2009) found a second increase in precipitation values at the beginning of the MCA, followed by a decline. The limited archaeological records for the last 1000 years (Franco et al., 2004) indicate low density of native population in several places of southern Patagonia. Therefore, vegetation changes during this period are attributed to natural factors. The regime shift analysis shows a change at $c .500 \mathrm{cal}$. yr BP (Figure $7 \mathrm{~b}$ ), associated with an abrupt change in the vegetation, triggered by an increase of moisture during the MCA, which in turn is linked to strengthening of the westerlies. Figure 7a shows a positive trend in the moisture balance with a peak at $c .570 \mathrm{cal}$. yr BP. These evidences support the idea that the MCA could have been a slightly wet period in South Patagonia.

'LIA' between C. 550 and 50 cal.yr BP (AD 1580-1900). During the LIA, the moisture balance index decreases (Figure 7a), as a result of the low Nothofagus values recorded during this period, condition that can be related to a weakening of the westerlies. In Cerro Frías sequence, Mancini (2009) shows a drop in Nothofagus values during the LIA, suggesting a reduction of the forest canopy and a development of an open landscape characterized by grass steppe. In addition, the quantitative reconstruction for this site shows a significant decrease in precipitation (Tonello et al., 2009). In Vega Nandú, an abrupt decline of Nothofagus forest occurs at c. 200 cal. yr BP (AD 1700), related to the European settlers (VillaMartínez and Moreno, 2007). Furthermore, Huber and Markgraf (2003) found a minor but consistent rise in a diverse range of herb, shrub and fern taxa, suggesting a slight opening of the forest after 350 cal. yr BP (AD 1600). In PAB, we found the highest values of palynological richness during this period (Figure 4). Moreno et al. (2009) infer close canopy forest dominating Lago Guanaco area between 550 and $60 \mathrm{cal}$. yr BP. However, this site recorded lower Nothofagus values during the LIA together with a maximum increase in Mulinum at c. 200 cal. yr BP. Similar results are found in our study (Figure 4). Also, the low temperature postulated for this period (Luckman and Villalba, 2001; Masiokas et al., 2009; Neukom et al., 2010; Villalba et al., 2003) might have enabled glacier advances and restricted the water availability, together with a decrease in Nothofagus values at PAB. Thus, we can interpret the LIA as a sub-century climatic variability period, with moisture pulses, varying according to the geographical location. Markgraf and Diaz (2000) and Huber and Markgraf (2003) proposed that the 'LIA' was, in some regions, a period of high climatic variability rather than a simple temperature decline as in other parts of the world.

\section{Climate variability}

The late Holocene climate was highly variable, in particular on decadal and annual time scales. Several studies have highlighted the effect of ENSO (Kilian and Lamy, 2012; Mancini, 2009; Markgraf et al., 2003) and the Antarctic Oscillation (AAO; Garreaud et al., 2009; Villalba et al., 2012) in Patagonia. ENSO plays an important role in driving the year-to-year variations in precipitation. Positive anomalies of ENSO are associated with weakening of permanent anticyclone of the South Pacific (Cerveny, 1998) and the frequent formation of temporary centre of high pressure to the south of $40^{\circ} \mathrm{S}$, blocking westerlies influence on the west coast of Patagonia. In contrast, La Niña events (negative anomalies of ENSO index values) are associated with a strengthening of the 


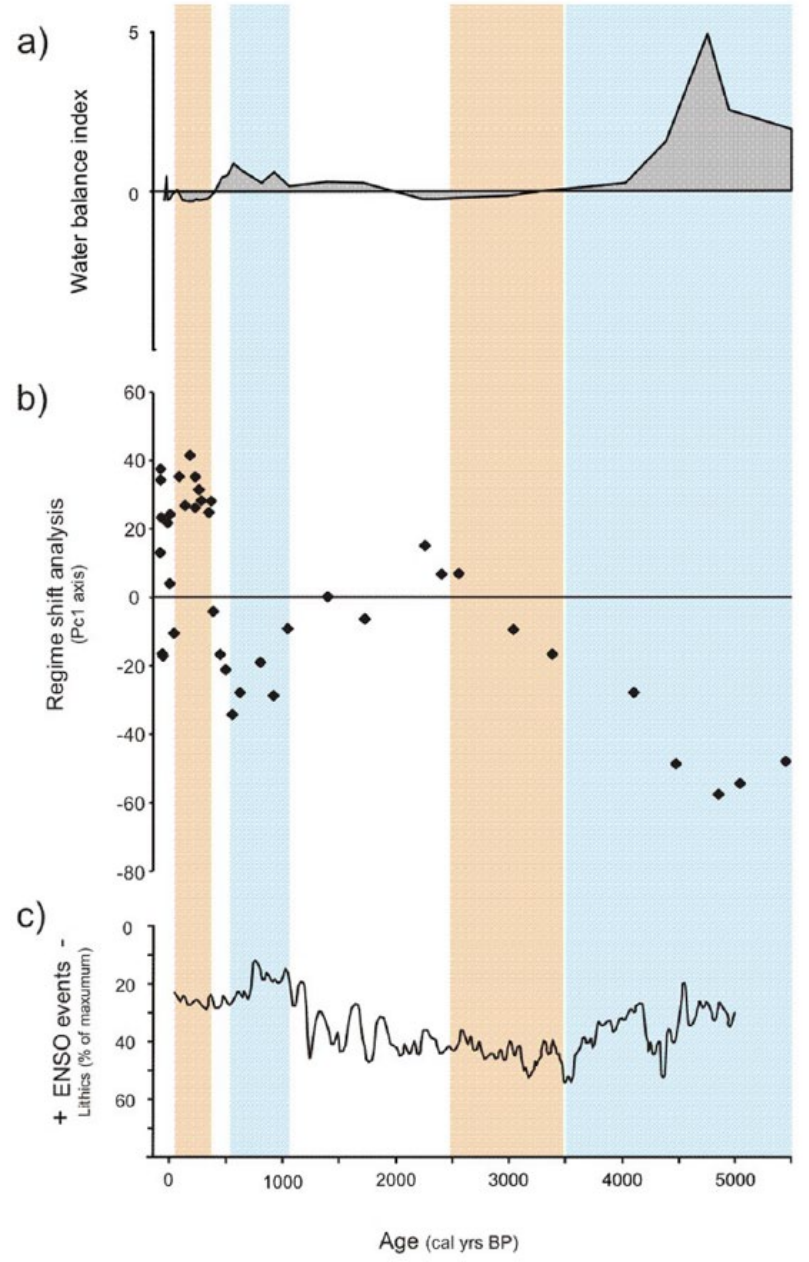

Figure 7. Comparison of (a) water balance index and (b) regime shift analysis record of Península Avellaneda Bajo with (c) ENSO frequency proposed by Rein et al. (2005). The periods of time discussed in Palaeoclimatic reconstruction section are highlighted in red and blue.

westerlies and slight increase in precipitation (Garreaud and Aceituno, 2007; Moy et al., 2002). The comparison between the moisture balance index and the ENSO reconstruction by Rein et al. (2005; Figure $7 \mathrm{a}$ and $\mathrm{c}$ ) offers the possibility to detect vegetation-ENSO synchronic behaviours at $50^{\circ} \mathrm{S}$. The ENSO reconstruction made by Rein et al. (2005) is a continuous and highly resolved record of El Niño events, represented by the amount of lithic grains in a sediment core from the Peruvian coast. During 3500-2500 cal. yr BP, the ENSO reconstruction shows positive phases (Niño events) coinciding with a decrease of the moisture balance index, probably associated to a weakening of the westerlies. Therefore, a strong influence of ENSO anomalies on the palaeoenvironmental variations of southwest Patagonia is suggested, supporting the later onset of the El Niño event at $c .1300$ cal. yr BP proposed by Kilian and Lamy (2012) to the Moy et al.'s (2002) ENSO reconstruction. Furthermore, the negative phase of AAO, also known as the Southern Hemisphere Annular Mode, is dominant when convection anomalies resemble 'El Niño' phases of ENSO. During the positive phase of AAO, an intensification and southward migration of the westerlies occurs (Garreaud et al., 2009). Several studies have reported significant anomalies in temperature and precipitation changes in most Southern Hemisphere continents that are related to changes in the AAO (Villalba et al., 2012). Also, Villalba et al. (2012) show negatives values of AAO during the 'LIA' in southern South America. During this period, the moisture balance index for the PAB record shows a negative trend (Figure 7a), which may be linked to a weakening of the westerlies. In these bases, this weakening of the westerlies could be related with a negative phase of AAO.

\section{Conclusion}

Closed Nothofagus forests dominated Península Avellaneda during the mid and late Holocene, between 5500-3600 and 2000 400 cal. yr BP, respectively. During these periods, westerly winds were strong, increasing local precipitation which in turn prevented fire activity.

At c. 3600 cal. yr BP, shrub communities, dominated by Asteraceae subf. Asteroideae, expanded in the region at the expense of Nothofagus forests. This open landscape became dominant for about 1400 years. The major physiognomic change occurred, however, between 400 and 200 cal. yr BP, when grass steppes replaced large extensions of forests. The occurrences of these two phases of open forests are associated to periods of weak Westerly flow. The consequent decrease in local precipitation together with the dominance of a more flammable patchy vegetation of shrub-forest or steppe-forest communities favoured the spread of fires.

The climatic anomaly events known as the MCA (c. 1450-450 cal. yr BP) and the 'LIA' (c. 550-50 cal. yr BP) are both characterized in the studied record by abrupt sub-century variations. The MCA period in South Patagonia has been slightly wetter, with higher temperatures and higher water balance than the 'LIA'. The latter also characterized by moisture pulses. European impact within the region has been significant since the 19th century, evidenced by fire events associated with fluctuations in palynological richness and the occurrence of anthropic taxa. The correspondence of moisture balance index and ENSO reconstruction raise the possibility that precipitation of Westerly origin was modified by ENSO fluctuations, as a possible ENSO-Southern Patagonia tele-connection.

\section{Acknowledgements}

We appreciate the assistance and critical discussions with colleagues from the Laboratory of Palaeoecology and Palynology, Mar del Plata University, which improved earlier versions of this manuscript. We thank Vera Markgraf and an anonymous reviewer for their valuable comments on the manuscript. The authors thank 'Administración de Parques Nacionales, Argentina (APN)' for allowing access to the workplace and 'Gendarmería Nacional (Calafate, Santa Cruz, Argentina)' for transporting us to the peninsula.

\section{Funding}

This work was financially supported by PIP CONICET 1265 and UNMDP-EXA 602/12. We thank the (NSF)-Arizona AMS Facility and $\mathrm{T}$ Jull for financial support for dating.

\section{References}

Adam DP and Mehringer PJ Jr (1975) Modern pollen surface samples: An analysis of subsamples. Journal of Research of the U.S. Geological Survey 3(6): 733-736.

Andersen T, Carstensen J, Hernández-García E et al. (2008) Ecological thresholds and regime shifts: Approaches to identification. Trends in Ecology and Evolution 24(1): 49-57.

Aniya M (1995) Holocene glacial chronology in Patagonia: Tyndall and Upsala Glaciers. Arctic and Alpine Research 27: 311-322.

Bamonte FP and Mancini MV (2011) Palaeoenvironmental changes since Pleistocene-Holocene transition: Pollen analysis from a wetland in southwestern Patagonia (Argentina). Review of Palaeobotany and Palynology 165: 103-110.

Bengtsson L and Enell M (1986) Chemical analysis. In: Berglund BE (ed.) Handbook of Holocene Palaeoecology and Palaeohydrology. Chichester: John Wiley \& Sons, pp. 423-451. 
Bennett KD (2003) 'psimpoll' and 'pscomb': C Programs for Analysing Pollen Data and Plotting Pollen Diagrams. Department of Archaeology and Palaeoecology, Queen's University Belfast. Available at: http://www.chrono.qub.ac.uk/psimpoll/ psimpoll.html.

Birks HJB and Line JM (1992) The use of rarefaction analysis for estimating palynological richness from Quaternary pollenanalytical data. The Holocene 2: 1-10.

Bradley RS, Hughes MK and Diaz HF (2003) Climate in Medieval time. Science 302: 404-405.

Brown CA (1960) Palynological Techniques. Baton Rouge, LA: Louisiana State University.

Cerveny R (1998) Present climates of South America. In: Hobbs JE, Lindesay JA and Bridgman HA (eds) Climates of the Southern Continents: Present, Past and Future. New York: John Wiley \& Sons, pp. 107-135.

Conedera M, Tinner W, Neff C et al. (2009) Reconstructing past fire regimes: Methods, applications, and relevance to fire management and conservation. Quaternary Science Reviews 28: 435-456.

de Porras ME, Maldonado A, Abarzúa AM et al. (2012) Postglacial vegetation, fire and climate dynamics at Central Chilean Patagonia (Lake Shaman, $44^{\circ} \mathrm{S}$ ). Quaternary Science Reviews 50: 71-85.

Donoso C, Steinke L and Premoli A (2006) Nothofagus antarctica (G. Forster) Oerst. In: Donoso C (ed.) Las especies arbóreas de los bosques templados de chile y Argentina. Autoecología. Valdivia: Marisa Cúneo Ediciones, pp. 401-410.

Faegri K and Iversen J (1989) Textbook of Pollen Analysis (ed Faegri K, Kaland PE and Krywinski K). Copenhagen: Wiley, $328 \mathrm{pp}$.

Fontana SL and Bennett KD (2012) Postglacial vegetation dynamics of western Tierra del Fuego. The Holocene 22(11): $1337-1350$

Fontana SL, Bianchi MM and Bennett KD (2012) Palaeoenvironmental changes since the Last Glacial Maximum: Patterns, timing and dynamics throughout South America. The Holocene 22(11): 1203-1206.

Franco NV, Borrero LA and Mancini MV (2004) Environmental changes and hunter-gatherers in southern Patagonia: Lago Argentino and Cabo vírgenes (Argentina). Before Farming 3: $1-17$.

Garreaud RD and Aceituno P (2007) Atmospheric circulation over South America: Mean features and variability. In: Veblen T, Young K and Orme A (eds) The Physical Geography of South America. Oxford: Oxford University Press, pp. 45-66.

Garreaud RD, Lopez P, Minvielle M et al. (2013) Large-scale control on the Patagonian climate. Journal of Climate 26: $215-230$

Garreaud RD, Vuille M, Campagnucci MR et al. (2009) Presentday South American climate. Palaeogeography, Palaeoclimatology, Palaeoecology 281: 180-195.

Glasser NF, Harrison E, Winchester V et al. (2004) Late Pleistocene and Holocene paleoclimate and glacier fluctuations in Patagonia. Global and Planetary Change 43: 79-101.

Grimm E (2004) Tilia Software. Springfield, IL: Research and Collections Center, Illinois State Museum.

Harrison S and Winchester V (2000) Nineteenth and twentiethcentury glacier fluctuations and climatic implications in the Arco and Colonia valleys, Hielo Patagonico Norte. Arctic, Antarctic, and Alpine Research 32(1): 55-63.

Heiri O, Lotter A and Lemcke G (2001) Loss on ignition as a method for estimating organic and carbonate content in sediments: Reproducibility and comparability of results. Journal of Paleolimnology 25: 101-110.
Higuera PE, Brubaker LB, Anderson PM et al. (2009) Vegetation mediated the impacts of postglacial climatic change on fire regimes in the south-central Brooks Range, Alaska. Ecological Monographs 79: 201-219.

Higuera PE, Peters ME, Brubaker LB et al. (2007) Understanding the origin and analysis of sediment charcoal records with a simulation model. Quaternary Science Reviews 26: 1790-1809.

Huber UM and Markgraf V (2003) European impact on fire regimes and vegetation dynamics at the steppe-forest ecotone of southern Patagonia. The Holocene 13: 567-579.

Huber UM, Markgraf V and Schäbitz F (2004) Geographical and temporal trends in late Quaternary fire histories of FuegoPatagonia, South America. Quaternary Science Reviews 23: 191-198.

Jobbágy EG, Paruelo JM and León RJC (1996) Vegetation heterogeneity and diversity in flat and mountain landscapes of Patagonia (Argentina). Journal of Vegetation Science 7: 599608.

Kelly RF, Higuera PE, Barrett CM et al. (2011) A signal-to-noise index to quantify the potential for peak detection in sedimentcharcoal records. Quaternary Research 75: 11-17.

Kilian R and Lamy F (2012) A review of Glacial and Holocene paleoclimate records from southernmost Patagonia (49$\left.55^{\circ} \mathrm{S}\right)$. Quaternary Science Reviews 53: 1-23.

Kitzberger T (2003) Regímenes de fuego en el gradiente bosqueestepa del noroeste de Patagonia: variacion espacial y tendencias temporales. In: Kunst CR, Bravo S and Panigatti JL (eds) Fuego en los ecosistemas argentinos. Santiago del Estero: INTA, pp. 79-92.

Kitzberger T (2012) Ecotones as complex arenas of disturbance, climate, and human impacts: The trans-Andean forest-steppe ecotone of northern Patagonia. In: Myster RW (ed.) Ecotones between Forest and Grassland, vol. 3. New York: Springer, pp. 59-88.

Kitzberger T, Aráoz E, Gowda JH et al. (2012) Decreases in fire spread probability with forest age promotes alternative community states, reduced resilience to climate variability and large fire regime shifts. Ecosystems 15: 97-112.

Lees K, Pitois S, Scott C et al. (2006) Characterizing regime shifts in the marine environment. Fish and Fisheries 7: 104-127.

Legendre PL and Birks HJB (2012) From classical to canonical ordination. In: Birks HJB, Lotter AF, Juggins S et al. (eds) Tracking Environmental Change Using Lake Sediments, Volume 5: Data Handling and Numerical Techniques. Dordrecht: Springer, pp. 201-248.

Luckman BH and Villalba R (2001) Assessing the synchroneity of glacier fluctuations in the western Cordillera of the Americas during the last millennium. In: Markgraf V (ed.) Interhemispheric Climate Linkages. New York: Academic Press, pp. 119-140.

McCormac FG, Hogg AG, Blackwell PG et al. (2004) SHCal04 Southern Hemisphere calibration 0-1000 cal BP. Radiocarbon 46: 1087-1092.

Mancini MV (2009) Holocene vegetation and climate changes from a peat pollen record of the forest-steppe ecotone, southwest of Patagonia (Argentina). Quaternary Science Reviews 28: 1490-1497.

Markgraf V and Diaz HF (2000) The past ENSO record: A synthesis. In: Diaz HF and Markgraf V (eds) El Niño and the Southern Oscillation: Multiscale Variability and Global and Regional Impacts. Cambridge: Cambridge University Press, pp. 465-488.

Markgraf V, Bradbury JP and Schwalb A (2003) Holocene paleoclimates of southern Patagonia: Limnological and environmental history of Lago Cardiel, Argentina. The Holocene 13: 581-591. 
Masiokas MH, Luckman BH, Villalba R et al. (2009) Little Ice Age fluctuations of small glaciers in the Monte Fitz Roy and Lago del Desierto areas, south Patagonian Andes, Argentina. Palaeogeography, Palaeoclimatology, Palaeoecology 281: 351-362.

Moreno PI, Francois JP, Moy CM et al. (2010) Covariability of the southern westerlies and atmospheric $\mathrm{CO}_{2}$ during the Holocene. Geology 38: 727-730.

Moreno PI, François JP, Villa-Martínez RP et al. (2009) Millennial-scale variability in Southern Hemisphere westerly wind activity over the last 5000 years in SW Patagonia. Quaternary Science Reviews 28(1-2): 25-38.

Moy CM, Dunbar RB, Moreno P et al. (2009) Isotopic evidence for hydrologic change related to the westerlies in SW Patagonia, Chile, during the last millennium. Quaternary Science Reviews 27(13-14): 1335-1349.

Moy CM, Seltzer GO, Rodbell DT et al. (2002) Variability of El Nino/Southern Oscillation activity at millennial timescale during the Holocene epoch. Nature 420: 162-165.

Neukom R, Luterbacher J, Villalba R et al. (2010) Multiproxy summer and winter surface air temperature field reconstructions for southern South America covering the past centuries. Climate Dynamics 37(1-2): 35-51.

Paruelo JM, Beltrán A, Jobbágy E et al. (1998) The climate of Patagonia: General patterns and controls on biotic processes. Ecología Austral 8: 85-101.

Pérez Moreau RA (1959) Reseña botánica sobre el Lago Argentino. Buenos Aires: Instituto Nacional del Hielo Continental Patagónico.

Perincioli H (2009) El lugar más bello y el más difícil ... Nicolás Stipicic y Florentina Vergara. The Austral Opinion Newspaper. Available at: http://www.laopinionaustral.com.ar.

Pisano EV and Dimitri MJ (1973) Estudio Ecológico de la Región Continental Sur del área Andino-Patagónica. Anales del Instituto de la Patagonia 4: 207-271.

Poletti Formosa RR (1979) La primera expedición hidrográfica inglesa al confin austral (1826-1830). Buenos Aires: Centro Naval, Instituto de Publicaciones Navales, 204 pp.

Rein B, Lückge A, Reinhardt L et al. (2005) El Niño variability of Peru during the last 20,000 years. Paleoceanography 20: PA4003.

Schäbitz F, Wille M, Francois JP et al. (2013) Reconstruction of palaeoprecipitation based on pollen transfer functions - The record of the last $16 \mathrm{ka}$ from Laguna Potrok Aike, southern Patagonia. Quaternary Science Reviews 71: 175-190.

Servicio Meteorológico Nacional (2012) Available at: http:// www.smn.gov.ar/serviciosclimaticos/.

Sottile GD, Bamonte FP, Mancini MV et al. (2012) Insights into Holocene vegetation and climate changes at the Southeast of the Andes: Nothofagus forest and Patagonian steppe fire records. The Holocene 22(11): 1309-1322.

Stern CR (2008) Holocene tephrochronology record of large explosive eruptions in the southernmost Patagonian Andes. Bulletin of Volcanology 70: 435-454.

Strelin JA and Malagnino EC (2000) Late-glacial history of Lago Argentino, Argentina, and age of the Puerto Bandera moraines. Quaternary Research 54: 339-347.

Strelin JA, Denton GH, Vandergoes MJ et al. (2011) Radiocarbon chronology of the late-glacial Puerto Bandera moraines, southern Patagonian icefield, Argentina. Quaternary Science Reviews 30: 2551-2569.

Stuiver M, Reimer PJ and Reimer RW (2005) CALIB 5.0.2. Available at: http://calib.qub.ac.uk/calib/.

Tolonen K (1983) The post-glacial fire record. In: Wein RW and MacLean DA (eds) The Role of Fire in Northern Circumpolar Ecosystems. New York: John Wiley \& Sons, pp. 21-44.

Tonello MS, Mancini MV and Seppä H (2009) Quantitative reconstruction of Holocene precipitation changes in southern Patagonia. Quaternary Research 72: 410-420.

Vidal OJ and Reif A (2011) Effect of a tourist-ignited wildfire on Nothofagus pumilio forests at Torres del Paine biosphere reserve, Chile (Southern Patagonia). Bosque 32: 64-76.

Villalba R, Lara A, Boninsegna JA et al. (2003) Large-scale temperature changes across the southern Andes: 20th-century variations in the context of the past 400 years. Climate Change 59: 177-232.

Villalba R, Lara A, Masiokas MH et al. (2012) Unusual Southern Hemisphere tree growth patterns induced by changes in the Southern Annular Mode. Nature Geoscience 5: 793798.

Villa-Martínez RP and Moreno PI (2007) Pollen evidence for variations in the southern margin of the westerly winds in SW Patagonia over the last 12,600 years. Quaternary Research 68: 400-409.

Wessa (2013) R: A Language and Environment for Statistical Computing (R Development Core Team 2011). Vienna: R Foundation for Statistical Computing. Available at: http:// www.R-project.org/.

White PS and Pickett STA (1985) Natural disturbance and patches dynamics: An introduction. In: Pickett STA and White PS (eds) The Ecology of Natural Disturbance and Patch Dynamics. Orlando, FL: Academic Press, pp. 3-13.

Whitlock C and Larsen CPS (2001) Charcoal as a fire proxy. In: Smol JP, Birks HJP and Last WM (eds) Tracking Environmental Change Using Lake Sediments, Volume 3: Terrestrial, Algal, and Siliceous Indicators. Dordrecht: Kluwer Academic Publishers, pp. 75-97.

Whitlock C, Moreno P and Bartlein PJ (2007) Climatic controls of Holocene fire patterns in southern South America. Quaternary Research 68: 28-36.

Whitlock C, Bianchi MM, Bartlein PJ et al. (2006) Postglacial vegetation, climate, and fire history along the east side of the Andes (lat 41-42.5), Argentina. Quaternary Research 66: 187-201.

Wille M and Schäbitz F (2009) Late-glacial and Holocene climate dynamics at the steppe-forest ecotone in southernmost Patagonia, Argentina: The pollen record from a fen near Brazo Sur, Lago Argentino. Vegetation History and Archeobotany 18(3): 225-234.

Wille M, Maidana N, Schäbitz F et al. (2007) Vegetation and climate dynamics in southern south America: The micro-fossil record of Laguna Potrok Aike, Santa Cruz, Argentina. Review of Paleobotany and Palynology 146(1-4): 234-246.

Willis KJ and Bhagwat SA (2010) Questions of importance to the conservation of biological diversity: Answers from the past. Climate of the Past 6: 759-769. 